\title{
Climate Change in Northern Quebec: Adaptation Strategies from Community-Based Research
}

\author{
MARTIN TREMBLAY, ${ }^{1}$ CHRISTOPHER FURGAL,${ }^{2}$ CAROLINE LARRIVÉE, ${ }^{3}$ TUUMASI ANNANACK,${ }^{4}$ \\ PETER TOOKALOOK,,${ }^{5}$ MARKUSI QIISIK, ${ }^{6}$ ELI ANGIYOU, ${ }^{7}$ NOAH SWAPPIE, ${ }^{8}$ JEAN-PIERRE SAVARD ${ }^{3}$ \\ and MICHAEL BARRETT ${ }^{9}$
}

(Received 26 June 2007; accepted in revised form 12 March 2008)

\begin{abstract}
Arctic communities are recently reporting warmer and shorter winters, which have implications for the ice season and, consequently, on the access to local territories and resources by members of these communities. These climatic shifts are resulting in increased risks for travel during the winter season associated with less stable and thinner ice. An integrated communitybased monitoring (ICBM) program was developed in Nunavik to generate adaptation tools to support safe access to land and resources and to enhance local adaptive capacity through participation in community-based monitoring activities. The Nunavik ICBM approach brings together partners (northern communities, Canadian universities, and various organizations) that have different perspectives on the issues surrounding land and resources in Nunavik. The ICBM project also brings together traditional knowledge and scientific knowledge, linking data collected through semi-structured interviews, local ethnocartographic interviews, and ice-monitoring activities with data gathered at weather stations. The partnership-based Nunavik ICBM program dealing with territory and resource access is an example of communities and scientists working together to improve our understanding of climate change impacts in the North, their importance for aboriginal people, and the ways in which an integrated, cooperative research process can develop local adaptive capacity.
\end{abstract}

Key words: adaptation, climate change, ice monitoring, integrated community-based monitoring, semi-structured interviews, northern Quebec, scientific knowledge, traditional knowledge

RÉSUMÉ. Les communautés arctiques rapportent depuis quelques années des hivers plus chauds et plus courts qui ont des implications sur la saison de glace et par conséquent sur l'accès au territoire et aux ressources locales par les membres de ces communautés. Ces conditions climatiques ont comme conséquence d'augmenter les risques lors des voyages hivernaux en raison de glaces instables et plus minces. Un programme intégré de surveillance des glaces (PISG) a été développé au Nunavik pour produire des outils d'adaptation visant à soutenir l'accès sécuritaire au territoire et aux ressources et pour augmenter la capacité d'adaptation locale par la participation communautaire aux activités de surveillance. L'approche du PISG rassemble plusieurs partenaires (les communautés nordiques, universités canadiennes et différents organismes) qui s'intéressent particulièrement aux questions d'accès au territoire et aux ressources au Nunavik et y apportent des perspectives variées. Le projet du PISG intègre le savoir traditionnel et le savoir scientifique utilisant plusieurs sources de données (provenant des entrevues semi-structurées, des entrevues ethno-cartographiques locales, de la surveillance de glace et des données météorologiques). Le PISG est un exemple de partenariat entre les communautés nordiques et les scientifiques qui permet de mieux comprendre les impacts des changements climatiques en cours dans le nord, leur importance sur les peuples autochtones et la façon dont la capacité d'adaptation locale peut être développée par une recherche intégrée et coopérative.

Mots clés: adaptation, changement climatique, surveillance de glace, suivi communautaire intégré, entrevues semi-structurées, Québec nordique, savoir scientifique, savoir traditionnel

\footnotetext{
${ }^{1}$ Renewable Resources Department, Kativik Regional Government, PO Box 9, Kuujjuaq, Québec J0M 1C0, Canada; mtremblay@ krg.ca

${ }^{2}$ Departments of Indigenous Studies and Environmental and Resource Studies, Trent University, 1600 West Bank Dr., Peterborough, Ontario K9J 7B8, Canada; chrisfurgal@trentu.ca

${ }^{3}$ Consortium Ouranos, 550 Sherbrooke Ouest, 19e étage, Montréal, Québec H3A 1B9, Canada

${ }^{4}$ Renewable Resources Department, Kativik Regional Government, PO Box 126, Kangiqsualujjuaq, Québec J0M 1N0, Canada

${ }^{5}$ Renewable Resources Department, Kativik Regional Government, PO Box 108, Umiujaq, Québec J0M 1Y0, Canada

${ }^{6}$ Renewable Resources Department, Kativik Regional Government, PO Box 130, Kangiqsujuaq, Québec J0M 1K0, Canada

${ }^{7}$ Renewable Resources Department, Kativik Regional Government, PO Box 74, Akulivik, Québec J0M 1V0, Canada

${ }^{8}$ Naskapi Nation of Kawawachikamach, Kawawachikamach, Québec G0G 2Z0, Canada

${ }^{9}$ Renewable Resources Department, Kativik Regional Government, PO Box 9, Kuujjuaq, Québec J0M 1C0, Canada

(C) The Arctic Institute of North America
} 


\section{INTRODUCTION}

Trail networks in Nunavik and northern Quebec are very important for local populations. They provide links between the communities in a region where no road network exists and communities are accessible only by plane or by boat. Trails are used to conduct traditional activities such as hunting, fishing, and trapping, which remain important for economic, cultural, and nutritional reasons (Myers et al., 2005; Van Oostdam et al., 2005). Climate change has begun to affect the timing and security of individuals' access to local environments and key food resources (Furgal et al., 2002; Lafortune et al., 2004), and the changes observed in this region also constitute critical social and economic issues for northern Quebec residents. In response to these changes, an integrated community-based monitoring (ICBM) program is being developed, and it is helping local populations to cope with climatic change and maintain traditional harvesting activities.

The Intergovernmental Panel on Climate Change (IPCC, 2007) reported that climate change has already started to occur in the polar regions. Change is resulting in warmer temperatures, mainly in winter, the impacts of which can be seen in the decreasing extent and thickness of sea ice, the melting of permafrost, increased coastal erosion, and changes in the distribution and abundance of key northern species. Moreover, the IPCC (2007) projects that this region will be affected by some of the largest and most rapid changes of any region in the world, which will have important consequences for both environmental and human systems in the North. Most climate models for the 21st century forecast increases in precipitation and temperature for the Arctic, especially during autumn and winter (ACIA, 2005).

In Nunavik, the 20th century was the warmest overall to date (Lavoie and Payette, 1992; Overpeck et al., 1997), but the significant warming trend observed elsewhere in the North occurred here only in the past 10 years. Some studies even observed a cooling trend in the region before that period (e.g., Allard et al., 1995). However, the warmer temperatures experienced since the mid-1990s have already had consequences for the environment (Allard et al., 2004). Local populations also report warmer and shorter winters (Lafortune et al., 2004; Community of Kangiqsujuaq et al., 2005) that affect the ice season, producing delayed freeze-up, thinner ice in winter, and earlier breakup.

Before, the snow and the land were solid enough [for harvesters] to travel safely. Because of global warming the situation has changed. They have to be more careful, and the routes that are taken during the winter are sometimes not frozen, especially the river.

(Quitsak Tarriasuk, Ivujivik)

Before, we could go along the shore in front of Umiujaq all the time. Now you have to be careful. It is only during real winter that you can use that area.... In May, the whole area is no longer passable. Back then we could have used dog teams. But now it is melting faster, the ice is going out faster.

(Davidee Niviaxie, Umiujaq)

Consequently, human access to local harvesting areas and resources is also affected (Lafortune et al., 2004; Tremblay et al., 2006). Given the new circumstances, harvesters must often use alternative trails or delay their activities and wait for better conditions.

It is mainly on the coast that we have problems [by snowmobile] because the ice is not frozen as much today as it used to be. In the past we could travel confidently but today the sea ice is melting near the current.

(Mattiusi Iyaituk, Ivujivik)

The difference between my regular routes and today is [that] I would normally be going fishing because there is usually snow at this time of year. But now, today [3 November 2005], there is still no snow.

(Henry Quissa, Akulivik)

Climatic changes have been well documented since the beginning of the Holocene (Alley, 2000; Korhola et al., 2002) and over the last few centuries (Overpeck et al., 1997). Several generations of Arctic peoples have used various strategies to cope with past changes (Nelson, 1969), and their adaptive capacity is well known (Robards and Alessa, 2004). Traditional knowledge systems are critical in supporting local adaptation to climate change (e.g., Krupnik and Jolly, 2002). Traditional knowledge (or TK) refers here to the cumulative body of knowledge, practice, and belief evolved through adaptive processes and handed down from generation to generation (Berkes, 1999). However, contemporary climatic changes seem to differ from earlier shifts in their intensity. New climate conditions are responsible for unprecedented environmental changes in some northern regions. In the case of ice dynamics, some local ice experts have difficulties describing these new environmental conditions. At the individual scale, therefore, TK may not always be effective in adapting to recent climatic change.

I can not answer you on this question [Can you tell me how you know when the ice is safe to travel on?] because now the ice behaviour is different than what it is used to be.

(Paulasi Qaunaaluk, Ivujivik)

The project "Access to Territory and Resources" was initiated by the Kativik Regional Government (KRG) in response to concerns expressed by northern Nunavik communities. Its principal objective is to enhance the capacity of local residents to adapt to climate change through their participation in community-based monitoring activities. This project has developed an integrated approach that brings together people from northern communities, regional administrative agencies, and universities in a 


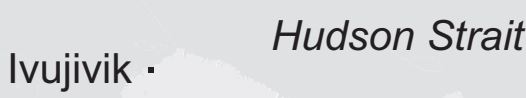

- Kangiqsujuaq

Akulivik .

Hudson Bay

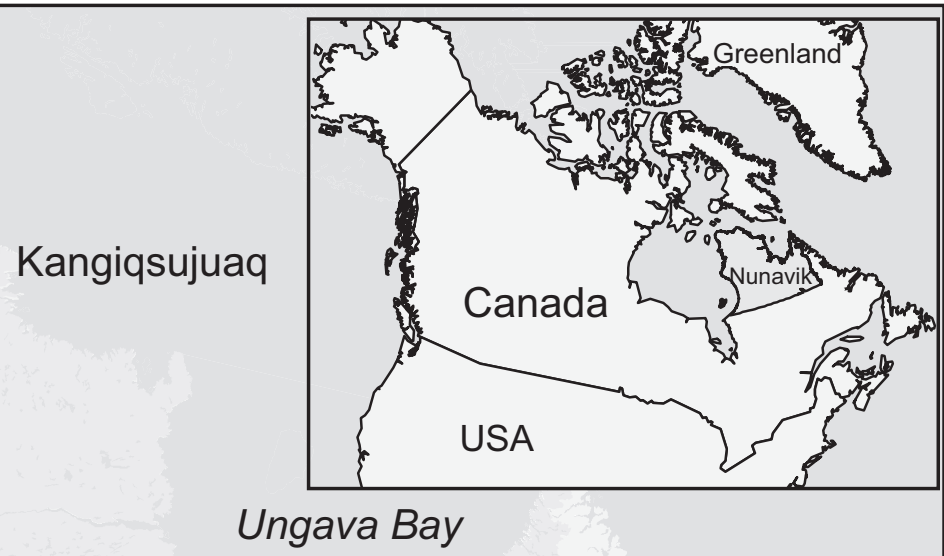

Ungava Bay

Kangiqsualujjuaq ·

Kuujjuaq.

Umiujaq ·

\section{Nunavik}

\section{Kawawachikamach .}

FIG. 1. Map of Nunavik, showing participating communities.

multidisciplinary initiative, involving both traditional and scientific knowledge, to study aspects of climatology, ice dynamics, human safety, and food security. Here we describe the integrated community-based monitoring (ICBM) model used to develop adaptation tools for safe access to land and resources in Nunavik communities.

\section{REGIONAL CONTEXT}

The Nunavik region comprises 14 communities located along the coasts of Hudson Bay, Hudson Strait, and Ungava Bay (Fig. 1). These communities are accessible only by plane or (in summer) by boat. Five Inuit communities (Akulivik, Ivujivik, Kangiqsualujjuaq, Kangiqsujuaq, and Umiujaq) and one Naskapi community (Kawawachikamach) were selected to participate because they are representative of the different bioclimatic zones that make up the region and because each community expressed interest in participating in the study. Kawawachikamach, the only community outside of the Nunavik region, is located inland just south of the Nunavik border $\left(55^{\circ} \mathrm{N}\right)$. This village is linked by road to the community of Schefferville, Quebec, which is accessible by train from the Lower North Shore of the St. Lawrence River. The other communities in the study are not linked by road to each other or to the rest of the province, much like communities in other northern regions of the country (e.g., the Baffin region of Nunavut, Nunatsiavut, and parts of the Northwest Territories). Winter trail networks throughout the region, composed of land and sea-ice trails that have been used for generations, are therefore particularly significant because they connect the communities to each other and provide access to traditional harvesting grounds during winter months. Many of the landbased trails are used all year round.

\section{PRELIMINARY STUDIES AND IDENTIFICATION OF PROJECT PRIORITIES}

The first phase of the project began in 2002-03 with community workshops in three communities, Kangiqsujuaq, 
Ivujivik, and Puvirnituq (Community of Kangiqsujuaq et al., 2005; Community of Ivujivik et al., 2005; Community of Puvirnituq et al., 2005). Each workshop brought together representatives from that community to discuss the changes that residents had observed in their local environment and their impact on the community and individuals' activities. The workshops confirmed the unpredictable weather and changing ice dynamics noted earlier, as well as their effects on the livelihood of communities dependent on harvesting local food resources.

The ICBM project, developed to address critical community concerns identified during the workshops (Community of Kangiqsujuaq et al., 2005; Community of Ivujivik et al., 2005; Community of Puvirnituq et al., 2005), has focused specifically on the issue of access to territory and resources. The project now involves several data sources and brings together traditional and scientific knowledge based on quantitative and qualitative analysis of ice conditions.

\section{COLLABORATION BETWEEN PARTNERS}

The Nunavik ICBM approach brings together partners with various perspectives on the issues related to access to territory and resources in Nunavik. Community participation, the cornerstone of the project, is organized and sustained by a local researcher responsible for developing research directions in each community and for liaison between community members and project scientists. Ideally, the goal is for the community to take as much responsibility as possible for the research project and to direct it toward finding the best solutions for issues that concern local residents. In general, the cooperation follows a basic process. Once issues have been identified, local authorities and scientific researchers, in cooperation with community or regional agencies, request resources from funding agencies. When funds have been allocated, communities are consulted and project goals and timelines are adopted. Initial background and TK interviews are conducted, and community-based monitoring work is then established and directed by the local researcher, with advice and cooperation of scientific researchers. Upon the completion of the work, the local researcher, community members, and scientific researchers work together to develop adaptation strategies. Finally, the local researcher disseminates adaptation tools within the community.

\section{Northern Authority and Scientific Researchers}

The Nunavik ICBM program was developed through partnerships of the KRG Renewable Resources Department and Parks Section with university-based scientists. Creating these partnerships constituted the first step in developing the network that supports the project today. The KRG has been responsible for planning since the project's inception, and the scientific partners have provided support in proposal writing, fundraising, training of individuals, and analysis of locally collected data. The ICBM was implemented in Nunavik communities under the direction and authority of the KRG. KRG Renewable Resources employees based in participating communities, who already had a strong interest in climate change and related impacts in their region, became the local researchers in the project. Their participation, first seen as supplementary to their originally scheduled work, is now an official component of their job description. A strong partnership was formed with scientists from the Nasivvik Centre at Laval University in Quebec City, who are dedicated to supporting community-based research initiatives through training and cooperative project development. This relationship has facilitated the conduct and analysis of local ethnocartographic interviews with hunters and elders related to community trail networks, local ice dynamics, and changes in local and regional climate patterns. Collaboration with climate-change researchers in Montreal (the Ouranos Consortium) and researchers at Laval University's Centre d'études nordiques has supported the quantitative analysis of climate indicators that complement the investigation into local changes and their impacts on human activities.

\section{Northern Communities}

The ICBM was implemented in northern Quebec communities in the spring of 2004. The development of partnerships with communities began with meetings and presentations to the municipal councils and the local hunting, fishing, and trapping associations. As the project was a response to requests at the community workshops, support for the initiative already existed in the communities, and these initial meetings constituted a project planning and adaptation phase. This first step ensured that the project would cover issues deemed significant at the individual community scale and provide benefits relevant to the local population.

Today, local involvement in the ICBM includes the sharing of local observation-based data and TK. Local researchers, with the help of scientists, gather this information directly through semi-structured interviews (as in Huntington, 1998) using an ethnocartographic process (Chapin and Threlkeld, 2001). In each community, interviews have been conducted with 5 to 10 elders or experienced hunters (Tremblay et al., 2006). Interview participants were recruited on the advice of the local hunters, fishers, and trappers' associations. Males comprised the large majority of participants, but some women were included upon recommendation of their expert knowledge of ice conditions or their frequency of travel. During these interviews, elders and hunters shared their observations and knowledge about changes in local climate conditions, changes in ice dynamics, and the impacts of these changes on the use of traditional trails and human safety while on the land (Table 1). Traditional trail mapping interviews had been conducted in the region by the Makivik 
TABLE 1. Community contributions to the integrated community-based monitoring (ICBM) program.

\begin{tabular}{ll}
\hline \hline Contributors & Contribution \\
\hline Experts on ice dynamics and traditional trails, & - Identification of concerns of the population \\
from six communities (Akulivik, Ivujivik, & - Community project support \\
Kangiqsualujjuaq, Kangiqsujuaq, & - Traditional knowledge (TK) on ice dynamics \\
Kawawachikamach and Umiujaq) & - Tey (environmental and climate) indicators of ice safety \\
in six bioclimatic zones & - TK on traditional trails \\
& - TK on climate change \\
& - Local information on trail conditions to validate the climate indicators of safe ice \\
\hline \hline
\end{tabular}

Corporation from the 1970s to the 1990s and these exist as part of their TK database. One of the key contributions to the communities in this KRG project has been to identify and document the increase in "risky areas" in local ice or land trails due to recognized changes in climate and weather variables. However, because environmental conditions are continuing to change in this region, these trail networks and the "risky area" maps must be updated regularly to keep them accurate enough to be useful to communities.

Participants know that communicating these local observations and TK is important to promoting and maintaining the safe practice of traditional land and sea activities and travel for current and future generations:

It would be best if this information is handed down to the next generation and was used by people growing up.

(Paulasi Qaunaaluk, Ivujivik)

Other interview participants saw an opportunity to update or learn from the TK shared in the project.

I would like the knowledge to be used because I have data [experiences] that were gathered 30 years ago and it will be good to update them to see if they are still true. It will be nice to see, for instance, if risky areas [that I have seen] are really still like that. It would be nice to get new data [observations] for the past 10 past years.

(Henry Alayco, Akulivik)

Local participation and knowledge are critical in the development of community adaptation strategies because adaptation tools already exist in TK systems. Indeed, this type of knowledge is community-specific, place-based, related to environment-dependant practices and developed through past and current experience (Berkes et al., 2000). It represents a local database of adaptive measures that will succeed in the local environment. The TK information collected from semi-structured interviews in this study is being used to develop a "safe practices guide" for land and ice travel. An interactive CD-ROM concerning access to local land and resources will contain results from the study on ice dynamics, as well as maps illustrating principal and alternative trails and risky areas around each participating community. Local participants have also provided weekly qualitative information on winter trail conditions, which is being used to identify and validate climatic indicators characterizing safe ice conditions from a local Inuit perspective and to generate new indicators for ice modeling. Local researchers collaborate with those at Ouranos to develop these climate indicators, using the quantitative and qualitative information collected during ice-monitoring activities in sea and lake environments (Tremblay et al., 2006).

\section{Local Researchers in Northern Communities}

The Nunavik ICBM is based on an "investigation in the North, for the North, and by the North" approach, which is essential to developing adaptive capacity at the local scale. To this end, one active and trained local researcher is present in each community except Ivujivik (the researcher from Akulivik is also responsible for Ivujivik). Local researchers play a critical role in the investigation and in maintaining a link between the communities and the scientists supporting the project. Local researchers are in charge of data collection, and they are partners with the scientists in developing adaptation strategies based on analysis and interpretation of results. For example, local researchers conduct the semi-structured interviews and collect the quantitative data from ice-monitoring activities; communicate project information to the local population; and in some cases, present study results on behalf of the project at scientific meetings and conferences outside of their region.

The training of local researchers has been a significant stage in the development of the ICBM. Prior to each winter, local researchers participate in a team meeting to plan and organize winter fieldwork. At this seasonal meeting, the local researchers can review methods used during the previous year and identify training needs related to these activities or associated with any new methods to be used in the upcoming season. At this time, the research team identifies appropriate training workshops or modules, and the local researchers receive training. Training on data entry, organization, and analysis is provided on an ongoing basis to ensure that local researchers can progressively take charge of the project in their own communities. Training for local researchers has included the conduct and transcription of semi-structured, ethno-cartographic interviews with experienced hunters and elders (Table 2, Fig. 2); the standardized collection of ice and snow data for the ice-monitoring activities at critical nodes in local trail 
TABLE 2. Contributions of local researchers to the integrated community-based monitoring (ICBM) program.

\begin{tabular}{ll}
\hline \hline Local Researchers learned to: & Local Researchers are responsible for: \\
\hline - Independently carry out interviews with elders and experienced hunters & ・ Interviewing elders and hunters \\
- Transcribe the interviews and translate them into English & $\bullet$ Translating and transcribing the interview tapes \\
- Collect standardized field data on ice and snow at weekly intervals & $\bullet$ Arranging activities for a mapping workshop \\
$\begin{array}{ll}\text { - Enter data in an electronic spreadsheet and create basic graphs illustrating changes in ice and snow } \\
\text { characteristics over the winter }\end{array}$ & $\bullet$ Computing field data \\
- Present project results orally & $\bullet$ Communicating study results to communities \\
\hline \hline
\end{tabular}

networks around their community; and the conduct of brief, key-informant interviews with harvesters regarding winter trail conditions (Table 2). Currently, weekly icemonitoring activities include taking measurements at two different sites, and both snow level and ice thickness are recorded from December to May (from freeze-up to breakup). The local researcher enters these data into a spreadsheet and sends it electronically to a central researcher responsible for coordinating activities in all the communities. This central researcher then posts the weekly data for public viewing on the project's web site (http:// climatechange.krg.ca). Thus, each community has access, via the Internet or the local researcher, to weekly updates of both quantitative measurements and qualitative observations by local experts of ice conditions in key locations around their community.

\section{BENEFITS FOR NORTHERN PEOPLE AND THE SCIENTIFIC COMMUNITY}

The Nunavik ICBM program has developed through strong community participation, and it strives to benefit local people by supporting their adaptations to changes in the local environment. In particular, the project helps to increase the community's capacity to collect, understand, deliver, and use local information related to climate and environmental change. The TK, local observations, and ice-monitoring information gathered in this project are made available to the local populations as soon as possible after they are collected and organized. The Internet mode of dissemination has become significantly more effective and acceptable in the region since the implementation of region-wide broadband access.

One objective of disseminating this information is to try to inform both active and future harvesters. This medium makes it possible to disseminate ice-monitoring information and details of trail conditions in real time. Throughout the ice season, it is possible to consult the weekly ice data for strategic locations along the winter trail networks and obtain information reported by local ice experts about the general conditions of the trail (e.g., "the ice is formed but you have to be careful because of the presence of open water near...," "the ice is safe to go anywhere along the trail," "the fast ice is still solid, but be careful near..."). Through the Internet it is also possible to disseminate updated regional maps, showing routes or trails used for snowmobile, dog team, ATV, kayak, peterhead (boat), speedboat, and canoe travel for each community (Fig. 2). Available in portable document format (PDF), the maps are easy to download and print and thus user-friendly for local residents.

The documents and communication tools can be updated periodically in response to feedback to the local researcher on how useful the community finds the website information. For example, users have commented on the scale of the maps, the symbols used, and the time required to download maps from the website, and the research team has used this information to improve these products. The website also provides access to information on weather conditions, weekly tide charts, and marine weather forecasts through links with Environment Canada and other agencies. As communities become more modern and more individuals engage in wage-earning employment during the week, yet still hunt and travel after work and on weekends, communications support such as the use of regional Internet sites to exchange and distribute information in the community is increasing in value.

The Nunavik ICBM has also used standard and accepted methods of data collection and analysis to ensure scientific quality. For example, interviews with elders and hunters on ice dynamics and climate change, ice-monitoring activities, and weather analysis all follow accepted scientific methods. Qualitative thematic content analysis (Creswell, 2003) of the interviews (regarding TK on regional trails and ice dynamics) has used the standard method of Tesch (1990). The ice-monitoring activities respect a strict protocol, and identical methods are used in all participating communities. Recently secured funding (ArcticNet) and collaboration with networks of scientists (University of Manitoba and Laval University) have allowed the acquisition of automated ice-monitoring stations, which further improve the quality of the local weather data. These stations could help, for example, to identify variables other than temperature (e.g., wind, humidity, solar radiation) that affect local sea-ice dynamics, but about which we currently have little understanding at the local scale. 


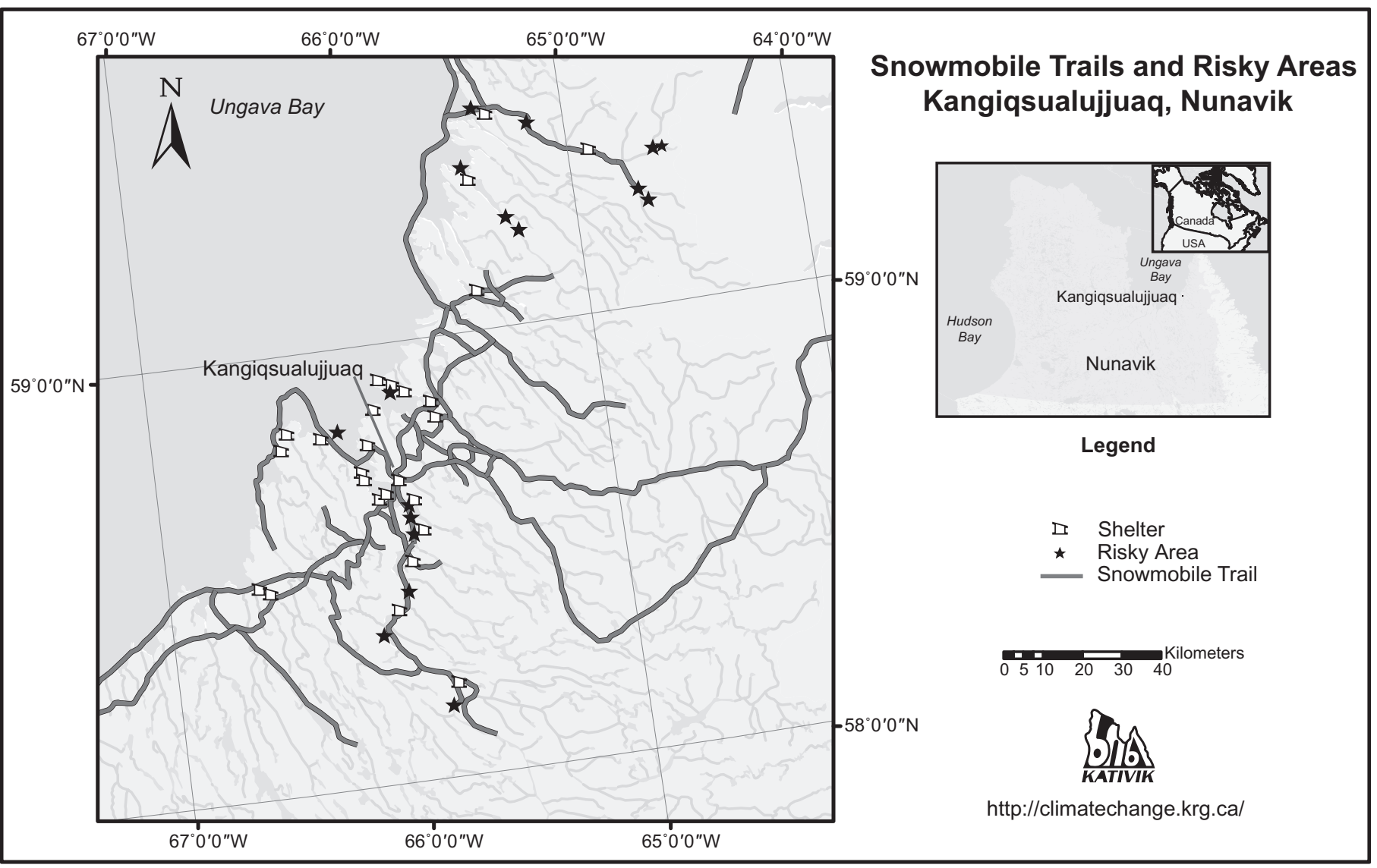

FIG. 2. Ethnocartographic map for the Kangiqsualujjuaq area. Users can download maps of trails and routes for ATV, dog team, kayak, canoe, peterhead (boat), snowmobile, and speedboat from the project website (http://climatechange.krg.ca) and print them in black and white or colour.

\section{CONCLUSION}

The Nunavik ICBM project promotes the development of adaptive capacity through participation of local populations in all aspects of the research process. This project takes a multidisciplinary approach, integrates several sources of data, and brings together traditional knowledge and scientific knowledge derived from quantitative and qualitative analyses in the natural and social sciences. Knowledge on climate and environmental change, ice dynamics, and local use of land and ice trails helps to identify current and potential problems and to develop adaptation tools that support safe access to territory and resources in Nunavik. The inclusion of both traditional and scientific knowledge has been essential to creating an understanding of climatic and environmental changes that respects both aboriginal perspectives and scientific views. As a result, the project is producing credible and relevant information to support adaptation to climate change by northern communities. Moreover, the multilevel partnership strategies developed in this project can be applied to other environmental issues. Such partnerships, which incorporate local involvement and expertise, bring benefits to communities while ensuring the scientific integrity of the project.

\section{ACKNOWLEDGEMENTS}

This project would not be possible without the ongoing support and participation of local experts who generously agreed to share their knowledge. We are also grateful to the following agencies for their financial support: the Northern Ecosystem Initiative, Environment Canada; the Climate Change Impacts and Adaptation Directorate, Natural Resources Canada; the Ouranos Consortium; ArcticNet; the Nasivvik Centre at Laval University; the Ministère des Transports du Québec; and the Kativik Environmental Advisory Committee. The project would not have been possible without the inkind contribution of the Renewable Resources Department and the Parks Section of the KRG. We also thank Dr. Dave Rosenberg, two anonymous reviewers, and all the individuals who provided comments and advice on project reports and other communication products.

\section{REFERENCES}

ACIA (ARCTIC CLIMATE IMPACT ASSESSMENT). 2005. Arctic climate impact assessment: Scientific report. Cambridge: Cambridge University Press. 1042 p.

ALLARD, M., WANG, B., and PILON, J.A. 1995. Recent cooling along the southern shore of Hudson Strait, Quebec, Canada, documented from permafrost temperature measurements. Arctic and Alpine Research 27(2):157-166. 
ALLARD, M., FORTIER, R., GAGNON, O., and MICHAUD, Y. 2004. Problématique du développement du village de Salluit, Nunavik. Salluit: Une communauté en croissance sur un terrain sensible au changement climatique. Available at Centre d'études nordiques, Université Laval, Québec, Québec G1K 7P4. 93 p.

ALLEY, R.B. 2000. The Younger Dryas cold interval as viewed from central Greenland. Quaternary Science Reviews 19 (1-5):213-226, doi:10.1016/S0277-3791(99)00062-1.

BERKES, F. 1999. Sacred ecology: Traditional ecological knowledge and resource management. Philadelphia: Taylor and Francis. 209 p.

BERKES, F., COLDING, J., and FOLKE, C. 2000. Rediscovery of traditional ecological knowledge as adaptive management. Ecological Applications 10(5):1251-1262.

CHAPIN, M., and THRELKELD, B. 2001. Indigenous landscapes: A study in ethnocartography. Arlington, Virginia: Center for the Support of Native Lands. 156 p.

COMMUNITY OF IVUJIVIK, FURGAL, C., QINUAJUAK, J., MARTIN, D., MARCHAND, P., and MOSS-DAVIES, P. 2005. Putting the human face on climate change: Perspective from Ivujivik, Nunavik. Ottawa: Inuit Tapiriit Kanatami, Nasivvik Centre for Inuit Health and Changing Environments at Université Laval, and the Ajunnginiq Centre at the National Aboriginal Health Organization. 26 p.

COMMUNITY OF KANGIQSUJUAQ, FURGAL, C., QIISIQ, M., ETIDLOIE, B., and MOSS-DAVIES, P. 2005. Putting the human face on climate change: Perspective from Kangiqsujuaq, Nunavik. Ottawa: Inuit Tapiriit Kanatami, Nasivvik Centre for Inuit Health and Changing Environments at Université Laval, and the Ajunnginiq Centre at the National Aboriginal Health Organization. $26 \mathrm{p}$.

COMMUNITY OF PUVIRNITUQ, FURGAL, C., QINUAJUAK, J., MARTIN, D., MARCHAND, P., and MOSS-DAVIES, P. 2005. Putting the human face on climate change: Perspective from Puvirnituq, Nunavik. Ottawa: Inuit Tapiriit Kanatami, Nasivvik Centre for Inuit Health and Changing Environments at Université Laval, and the Ajunnginiq Centre at the National Aboriginal Health Organization. 23 p.

CRESWELL, J.W. 2003. Research design: Qualitative, quantitative and mixed methods approaches. Thousand Oaks, California: Sage Publications. 274 p.

FURGAL, C., MARTIN, D., and GOSSELIN, P. 2002. Climate change and health in Nunavik and Labrador: Lessons from Inuit knowledge. In: Krupnik, I., and Jolly, D., eds. The earth is faster now: Indigenous observations of Arctic environmental change. Washington, D.C.: Arctic Research Consortium of the United States and the Arctic Studies Center, Smithsonian Institution. 266-300.

HUNTINGTON, H.P. 1998. Observations on the utility of the semi-directive interview for documenting traditional ecological knowledge. Arctic 51(3):237-242.

IPCC (INTERGOVERNMENTAL PANEL ON CLIMATE CHANGE). 2007. Climate 2007: The physical science basis. Contribution of Working Group I to the Fourth Assessment Report of the IPCC. 996 p. Available at http://www.ipcc.ch/.
KORHOLA, A., VASKO, K., TOIVONEN, H.T., and OLANDER, H. 2002. Holocene temperature changes in northern Fennoscandia reconstructed from chironomids using Bayesian modeling. Quaternary Science Reviews 21:1841-1860.

KRUPNIK, I., and JOLLY, D., eds. 2002. The earth is faster now: Indigenous observations of Arctic environmental change. Washington, D.C.: Arctic Research Consortium of the United States and the Arctic Studies Center, Smithsonian Institution. $356 \mathrm{p}$.

LAFORTUNE, V., FURGAL, C., DROUIN, J., ANNANACK, T., EINISH, N., ETIDLOIE, B., QIISIQ, M., TOOKALOOK, P., and COMMUNITIES OF KANGIQSUJUAQ, UMIUJAQ, KANGIQSUALUJJUAQ, and KAWAWACHIKAMACH. 2004. Climate change in northern Québec: Access to land and resource issues. Project initiative of the Kativik Regional Government, Kativik Regional Government, Progress Report. Kuujjuaq, Québec: KRG. 36 p.

LAVOIE, C., and PAYETTE, S. 1992. Black spruce growth forms as a record of a changing winter environment at treeline, Quebec, Canada. Arctic and Alpine Research 24(1):40-49.

MYERS, H., FAST, H., BERKES, M.K., and BERKES, F. 2005. Feeding the family in times of change. In: Berkes, F., Huebert, R., Fast, H., Manseau, M., and Diduck, A., eds. Breaking ice: Renewable resource and ocean management in the Canadian North. Calgary: University of Calgary Press. 23-45.

NELSON, R.K. 1969. Hunters of the northern ice. Chicago: The University of Chicago Press. 429 p.

OVERPECK, J., HUGHEN, K., HARDY, D., BRADLEY, R., CASE, R., DOUGLAS, M., FINNEY, B., GAJEWSKI, K., JACOBY, G., JENNINGS, A., LAMOUREUX, S., LASCA, A., MacDONALD, G., MOORE, J., RETELLE, M., SMITH, S., WOLFE, A., and ZIELINSKI, G. 1997. Arctic environmental change of the last four centuries. Science 278(5341): 1251 - 1256, doi:10.1126/science.278.5341.1251.

ROBARDS, M., and ALESSA, L. 2004. Timescapes of community resilience and vulnerability in the circumpolar North. Arctic 57(4):415-427.

TESCH, R. 1990. Qualitative research: Analysis types and software tools. New York: Falmer Press. 330 p.

TREMBLAY, M., FURGAL, C., LAFORTUNE, V., LARRIVÉE, C., SAVARD, J.-P., BARRETT, M., ANNANACK, T., EINISH, N., TOOKALOOK, P., and ETIDLOIE, B. 2006. Communities and ice: Linking traditional and scientific knowledge. In: Riewe, R., and Oakes, J., eds. Climate change: Linking traditional and scientific knowledge. Winnipeg: University of Manitoba Aboriginal Issues Press. 123-138.

VAN OOSTDAM, J., DONALDSON, S.G., FEELEY, M., ARNOLD, D., AYOTTE, P., BONDY, G., CHAN, L., DEWAILLY, E., FURGAL, C.M., KUHNLEIN, H., LORING, E., MUCKLE, G., MYLES, E., RECEVEUR, O., TRACY, B., GILL, U., and KALHOK, S. 2005. Human health implications of environmental contaminants in Arctic Canada: A review. Science of the Total Environment 351-352:165-246, doi:10.1016/j.scitotenv.2005.03.034. 